\title{
Gemi Adamlarının İş Tatmini ve Örgütsel Bağlılık Düzeylerinde Farklılık Olan Demografik Faktörlerin Hiyerarşisi
}

\section{The Hierarchy of Demographic Factors Affecting Job Satisfaction and Organizational Commitment of Seafarers}

\author{
Elif Bal Beşikçi a,", Aydın Şıımantepe ${ }^{b}$ \\ $a^{a^{*}}$ Dr. Öğr. Üyesi, İstanbul Teknik Üniversitesi, Denizcilik Fakültesi, Deniz Ulaştırma İşletme Bölümü, 34940, İstanbul/Türkiye. \\ ORCID: 0000-0002-7882-8292
}

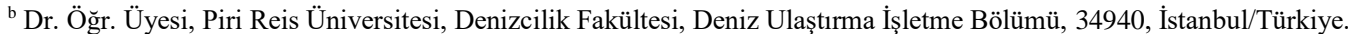
ORCID: 0000-0002-3781-1806

\section{MAKALE BİLGİSİ \\ Makale Geçmişi: \\ Başvuru tarihi: 01 Ocak 2020 \\ Düzeltme tarihi: 03 Nisan 2020 \\ Kabul tarihi: 20 Nisan 2020}

\section{Anahtar Kelimeler:}

İş Tatmini

Örgütsel Bağlılık

Gemi adamı Eksikliği,

Motivasyon ve Gemi adamı

\section{A R T I CLE INFO}

\section{Article history:}

Received 01 January 2020

Received in revised form 03 April 2020

Accepted 20 April 2020

\section{Keywords:}

Job Satisfaction

Organizational Commitment

Lack of Seafarers

Seafarer and Motivation
ÖZ

$\mathrm{Bu}$ araştırma gemi adamlarının örgütsel bağlılık ve iş tatmini düzeylerinin, sahip oldukları demografik özellikleri ile etkileşimini nicel olarak incelemeyi hedefleyen bir çalışmadır. Örneklem grubunu farklı pozisyonlarda çalışan gemi adamları oluşturmuştur. Araştırmanın çözümleme aşamasında, Minnesota İş Tatmin Ölçeğinden ve Allen ve Meyer Örgütsel Bağlılık Ölçeğinden faydalanılmıştır.

Çalıșmadan elde edilen sonuçlar göstermiștir ki; gemi adamlarının iș tatmini ve örgütsel bağlılık düzeyleri demografik faktörlere göre farklılık göstermektedir. Örgütsel bağll1ık alt boyutlarına bakıldığında ise çalışanların devamlılık ve duygusal bağlılık düzeylerinin yüksek olduğu görülmektedir. İş tatmini açısından ise, örgütsel düzeydeki iş tatmininin yüksek olduğu ortaya çıkmaktadır. Çalışma, gemi adamlarının hangi demografik özelliklerinin iş tatminlerini ve örgütsel bağlılıklarını daha fazla etkilediğini ortaya koymak yönüyle literatüre katkıda bulunmaktadır.

\section{A B S T R A C T}

This paper aims to quantitatively investigate the relation between seafarers' organizational commitment, job satisfaction and their demographic characteristics. Sample group consists of seafarers with different ranks. For analysis purposes Minnesota Job Satisfaction Scale, as well as Allen and Meyer Organizational Commitment Scale is used.

Results indicate that job satisfaction and organizational commitments of seafarers differ according to their demographic characteristics. Findings also indicate that affective and continuance commitment levels are noticeably high. One other important result is that organizational level is the highest job satisfaction level among the others. The results obtained intend to contribute to existing literature by pinpointing which demographic characteristics affect seafarers' job satisfaction and organizational commitments.

\section{Giriş}

Küresel boyutta, denizcilik sektöründe başta zabitler olmak üzere aktif çalışan gemi adamı sayısındaki eksiklik önemini sürdürmektedir (Nguyen vd., 2014). Buna paralel olarak, küresel ölçekteki gemi adamı talebi de kayda değer ölçüde artmaya devam etmektedir. Deniz ticaret filosu bir yandan dünya çapında genişlemesini sürdürürken geleneksel denizci uluslardaki gemi adamlarının yavaş yavaş emekli olması sektöre gerekli olan nitelikli zabit sayısında ciddi boyutta bir ihtiyaç doğmasına neden olmuştur (Fan vd., 2017).

\footnotetext{
* Sorumlu yazar/Corresponding author.

E-posta: bale@itu.edu.tr
} 
Uluslararas1 Denizcilik Örgütü IMO (International Maritime Organization) yakın gelecekte uygun yeteneklerle donatılmış özellikle de zabit sınıfından gemi adamlarına olan ihtiyacın devam edeceğini öngörmektedir (IMO, 2008; 2017).

Alarm veren nitelikte olan bu bulgu, Denize gidin ("Got to Sea") ve Denizciler Günü ("Day of the Seafarers") gibi bir dizi uluslararası kampanyanın başlatılmasına yol açmışıtır. $\mathrm{Bu}$ iki inisiyatif de hükümetleri denizde çalışmayı teşvik edici tavır almaya ve gemi adamlarının çalışma ve yaşama koşulları konusunda daha hassas olmaya yöneltmektedir. (IMO, 2008; 2017) Bu kampanyalara paralel olarak son dönem denizcilik literatürünün de denizcilik firmalarına insanları deniz yaşamına çekebilecekleri birçok yeni stratejiyi de önermeye başladığı görülmektedir. (Yuen vd., 2018). Örneğin Thai vd. (2013) bir denizcilik firmasını tercih edilen işveren bazlı markalaştırma stratejileri ortaya koymuştur. Ruggunan ve Kanengoni (2017) tarafindan yapılan bir araştırma ise, denizcilik öğrencilerinin \%55'nin denizdeki kariyerlerini 10 yıl ile sınırlamayı düşündüklerini ortaya koymuştur ki bu durum da halen hizmet yapan gemi adamlarını meslekte tutmanın önemini bir kez daha vurgulamaktadır.

Denizcilik şirketleri tarafından bakıldığında, gemi adamlarını elde tutma yetisi birçok avantaj sunmaktadır. Öncelikle, piyasada var olan yetişmiş ve yetkin personel açığı da dikkate alındığında, tecrübeli personeli elde tutmak, firmanın rekabet gücünü artırabilir. Bu personelin şirket içinde tutulması, kazanılması uzun süreçler alan bilgi birikimini ve yaşayarak deneyimlenmiş yetenek ve birikimi de şirket içinde tutulmasını sağlayacaktır. Öğrenme ve deneyim ile elde edilen bu değerli bilgi havuzu, birikim ve tecrübe, nihayetinde hem şirkete yeni katılacak genç gemi adamlarına hem de deniz taşımacılığının karadaki bacağını oluşturan aktiviteleri yöneten kadroya da aktarılabilecektir (Yuen vd., 2018).

$\mathrm{Bu}$ çalışmada, gemi adamlarının işlerine yönelik hissettikleri tatmin duygusu ile şirketlerine karşı hissettikleri bağlılık duyguları arasındaki ilişki ele alınmış ve bu ilişkinin demografik etkenlerden nasıl etkilendiği araştırılmıştır. Yapılan anketler ile gemi adamlarından toplanan veriler analiz edilmiş çıkan sonuçlara göre sektöre ilişkin sorunlar saptanarak çözüm önerileri getirilmiştir.

Çalışmada iş tatmin düzeyini tespit etmek için Minnesota İş Tatmini Ölçeği kullanılmış ve tatmin düzeyleri bireysel, örgütsel ve yönetsel tatmin olmak üzere üç başlıkta incelenmiştir. Öte yandan, örgütsel bağlllık ile ilgili olarak yapılan değerlendirmelerde Allen ve Meyer tarafindan ortaya konulan ve duygusal, normatif ve devam bağll11k boyutlarını kapsayan ölçek ele alınmıştır. Takip eden bölümlerde kullanılan yöntemler, örneklem grubu, hipotezler sunulmuş, bulgular analiz edilerek değerlendirme ve sonuçlara varılmıştır.

\section{Araştırmanın Yöntemi}

Araştırma hedefleri doğrultusunda; gemiadamlarının yapmakta oldukları işe yönelik hissettikleri tatmin duygusu ile şirketlerine karşı hissettikleri bağlılık duyguları arasındaki ilişki ve bu ilişsinin demografik etkenlerden nasıl etkilendiği araştırmak maksadıyla bir anket hazırlanmış ve üç bölüm altında incelenecek olan doğrudan veri toplanması yöntemi seçilmiştir.

Üç bölümden oluşan anket etik kurallara uygun olarak düzenlenmiştir. (13.04.2020 tarihli 139 numaralı etik kurul belgesi) Anketin birinci bölümünde katılımcılara ilişkin demografik veriler ile çalışma durumlarına yönelik 10 madde yer almıştır. Demografik veriler katılımcıların, yaşı, cinsiyeti, medeni durumu, eğitim durumu, gemide çalıştı̆̆ 1 bölüm ve görevini içerirken bu bölüm bir yandan da şirkette çalışma süresi ile bağlı bulunduğu amiri hakkındaki bilgileri edinmeyi hedeflemiştir.

İkinci bölüm temel olarak Meyer ve Allen tarafindan ortaya konulan Örgütsel Bağlılık Modelinin kullanılmasını içermiştir. $\mathrm{Bu}$ model doğrultusunda, elde edilen veriler kullanılarak katılımcilardan alınan cevaplar "duygusal bağlılık", "devamlılık bağl1lı̆ğ" ve "normatif bağlllık" olarak değerlendirilmiştir.

Allen ve Meyer'in (1990) örgütsel bağl1lık yaklaşımı, incelenen kitlenin hem tutumsal ve davranışsal yaklaşımlarını hem de bunların tamamlayıcı ilişkilerini birlikte ele almaktadır. Buna göre örgütsel bağlllık kavramı, kişilerin yer aldıkları organizasyona yönelik duyguları ve inançlarının bütünüyle ilgili psikolojik durumunu ifade eden bir kavram olarak görülmektedir. Ortaya konulan bu yaklaşımda, üç farklı boyutu olan bir bağlılık kavramı esas alınmaktadır. Buna göre "duygusal", "devamll11k" ve "normatif" bağlllık çözümlenen üç ana unsurdur. Duygusal bağlılık ile kişi, kendi istek ve seçimiyle çalıştığ organizasyon ile özdeşleşir ve içinde kalmayı benimser. Devamlılık bağlılığı, bireyin örgütten ayrılması durumunda maruz kalacağını öngördüğü olumsuzluklarla ilgilidir. Diğer bir deyişle, çalışanın örgütten ayrılması durumunda, bunun kendisine getireceği maliyeti ve kayıpları, buna karşılık örgütte kalmasının ona sağladığı faydaları değerlendirerek örgütte kalmayı seçmesidir. Normatif bağlılık, bireyin örgütte kalmak konusunda hissettiği içsel zorunlulukla ilgilidir. Yani birey sahip olduğu pozisyondan kaynaklanan sorumluluk ve görev duygusuyla, örgüte karşı kendisini bağlı hisseder ve örgütte kalmayı seçer. (Allen ve Meyer, 1990; Erdil vd. 2003; Meyer ve Allen, 1991; Özutku, 2008).

Bağlllık düzeyini ölçmeye yönelik Bülbül'ün 2016 yılındaki çalışmasında yer alan Likert tipi ölçek kullanılarak toplamda 17 maddelik anket uygulanmıştır (Bülbül, 2016). Bu maddeler bazında değerlendirildiğinde duygusal bağlllığı ölçmek için 1-2-3-13-15-16-17 numaralı maddeler; devam bağlılı̆ıını ölçmek için 5-6-7-8-9 numaralı maddeler ve normatif bağlllığı ölçmek için ise 1011-12-14 numaralı olanlar sorulmuştur. Ölçekte yer alan 4 numaralı ifade ise (devam bağllığını ölçmekte kullanılan) çalışmanın Cronbach alfa değerini düşürdüğünden dolayı çözümlemenin ilerleyen aşamaları öncesi değerlendirme dışı bırakılmıştır. Kullanılan ölçekte sunulan seçenekler ise; "Kesinlikle katılmıyorum", "Katılmıyorum", "Kararsızım", "Katıllyorum" ve "Kesinlikle katılıyorum" şeklinde oluşturulmuş ve analiz maksatlarıyla 1 'den 5'e kadar değer atanmıştır. Anket sonuçları SPSS 15.0 yazılımı kullanılarak faktör analizi yapılmış ve bağlılık boyutları ve demografik etkenler incelenmiştir.

Üçüncü bölümde; Minnesota İş Tatmini Ölçeği kullanılarak, bireyin işe ilişkin tatmini "yönetsel iş 
tatmini", "bireysel iş tatmini" ve "örgütsel iş tatmini" olarak incelenmiştir. Minnesota Tatmin Ölçeği (MSQ) 1967 yılında Weiss Davis, England ve Lofquist tarafindan geliştirilmiş,1985 yılında da Aslı Baycan tarafından Türkçe'ye çevrilmiş ve geçerlilik ve güvenilirlik çalışmaları yapılmıştır (Cronbach Alpha= 0.77) (Baycan, 1985). Bu ölçek incelemeyi biri uzun, diğeri kısa olan iki form üzerinden yapar. Uzun formunda toplam 100 madde bulunur. Bu maddeler her birinde 5 madde bulunan 20 alt boyuttan oluşur. Kisa form ise bu yirmi alt boyutun her birinden madde test korelasyonu en yüksek olanın seçilmesiyle oluşturulan toplamda 20 maddelik bir ölçektir. $\mathrm{Bu}$ çalışmada kısa formu olan toplam 20 madde kullanılmıştır. Bunlardan 1-7-8-9-10-11-12-13-14 numaralı olanlar bireysel iş tatminini; 2-3-4-15-18 numaralı olanlar örgütsel iş tatminini ve 5-6-16-17-19-20 numaralı olanlar da yönetsel iş tatmini tespit etmeyi amaçlamıştır. Formda yine Likert tipi ölçek kullanılmıştır. Ölçekteki seçenekler; "Hiç memnun değilim", "Memnun Değilim", "Kararsızım", "Memnunum ve "Kesinlikle Memnunum" seçeneklerinde olup ve analiz maksatlarıyla 1'den 5'e kadar değer atanmıştır.

Araştırma sürecinde bir sonraki adıma geçmeden önce iş tatmini ve örgütsel bağlılık ölçeklerinin güvenilirlik kontrolleri tamamlanmış, daha sonra bu konuda ortaya konan hipotezler test edilmiştir. Güvenirlik analizi yapılırken, literatürden elde edilen ifadeler, kendi ait oldukları boyut içerisindeki diğer ifadelerle beraber değerlendirilerek tek boyutluluk çözümlemesi yapılmıştır. Örgütsel bağlılık ölçeğindeki ifadelerden faktör yükleri 0,50'nin altında kalan ve Cronbach alfa değerlerini düşüren ifade (ki bu devam bağlılığını ölçmekte kullanılan 4 nolu ifadedir) çözümlemenin ilerleyen aşamaları öncesi değerlendirme dışı bırakılmıştır. Bu işlemden sonra, her bir boyutta bulunan ifadelerin güvenirlik analizleri yapılarak Cronbach alfa değerleri tespit edilmiştir. Tablo-2 ve Tablo3' den görüleceği üzere, alfa değerleri 0.70'nin üzerinde tespit edilmiş ve söz konusu ölçeklerin güvenilirlikleri değerlendirilmiştir (Nunnally, 1978).

\section{Araştırmanın Örneklemi}

Araştırmanın örneklem grubunu farklı denizcilik firmalarında çalışan 199 gemi adamı oluşturmuştur. Katılımcıların örneklem grubunu doğru ve tam temsil etmesi sağlamak açısından, araştırmaya katılan gemi adamlarının farklı gemilerde çalışıyor olmasına, hem güverte hem de makine bölümü personelini içermesine ve en alt düzeyde görevi olandan en üst düzeydeki yöneticiye kadar her düzeyi temsil etmesine özel önem verilmiştir. Ayrıca, araştırmada kullanılan ölçümler herkese açık online bir platformda ve kimlik/firma bilgileri istenmeden uygulanmıştır.

\section{Araştırmanın Hipotezleri}

Araştırmanın anlamlı sonuçlara ulaşabilmesi ve sonuçların ölçülebilir halde ifade edilebilmesi için analize esas olacak konularda hipotezler ortaya konulmuştur. Temel sorusu bireyin çalışmakta olduğu örgüte olan bağlılığı ile işine yönelik hissettiği tatmin arasında olabilecek anlamlı bir ilişkinin araştırılması olan bu çalışma aşağıda sunulan hipotezler ortaya konmuştur:
H1: Gemi adamlarının iş tatminleri ile örgütsel bağlılık seviyeleri öğrenim durumuna göre değişir.

H2: Gemi adamlarının iş tatminleri ile örgütsel bağlılık seviyeleri gemide çalıştıkları pozisyona göre değişisir.

H3: Gemi adamlarının iş tatminleri ile örgütsel bağlılık seviyeleri bağlı oldukları denizcilik şirketinde çalıştıkları süreye göre değişir.

H4: Gemi adamlarının iş tatminleri ile örgütsel bağlılık seviyeleri bağlı bulundukları amire göre değişir.

H5: Gemi adamlarının örgütsel tatminleri ile duygusal bağlılık seviyesi arasında pozitif ve anlamlı bir ilişki vardır.

H6: Gemi adamlarının yönetsel tatminleri ile duygusal bağlılık seviyesi arasında pozitif ve anlamlı bir ilişki vardır.

H7: Gemi adamlarının bireysel tatminleri ile duygusal bağlılık seviyesi arasında pozitif ve anlamlı bir ilişki vardır.

H8: Gemi adamlarının örgütsel tatminleri ile devamlılık bağlılık seviyesi arasında pozitif ve anlamlı bir ilişki vardır.

H9: Gemi adamlarının yönetsel tatminleri ile devamlılık bağlılık seviyesi arasında pozitif ve anlamlı bir ilişki vardır.

H7: Gemi adamlarının bireysel tatminleri ile devamlılık bağlılık seviyesi arasında pozitif ve anlamlı bir ilişki vardır.

H8: Gemi adamlarının örgütsel tatminleri ile normatif bağlılık seviyesi arasında pozitif ve anlamlı bir ilişki vardır.

H9: Gemi adamlarının yönetsel tatminleri ile normatif bağlılık seviyesi arasında pozitif ve anlamlı bir ilişki vardır.

H10: Gemi adamlarının bireysel tatminleri ile normatif bağlılık seviyesi arasında pozitif ve anlamlı bir ilişki vardır.

\section{Bulgular}

Araştırma bulgularının değerlendirmesinde öncelikle her iki ölçeğe ilişkin güvenirlik analizleri yapılmıştır. Sonrasında tüm alt boyutların ortalama değerleri ve standart sapmaları tablo şeklinde listelenmiştir. Verilerin işlenmesi, alt boyutların iş tatmini ve örgütsel bağlılık arasındaki ilişkileri ortaya çıkaracak şekilde ele alınmasıyla gerçekleştirilmiştir. Değişkenler arasındaki ilişki varyans analizi (ANOVA) ve Post-Hoc Tukey HSD testi ile çözümlemeye tabi tutulmuştur.

Katılımcılardan alınan demografik girdiler ve çalışma yaşamı konusunda elde edilen istatistiksel veriler Tablo-1 de sunulmuştur. Katılımcıların \%79'unu erkekler oluşturmuştur. 41 kadın katılımcının tamamı ise 4 yıllık fakülte mezunu olup zabit olarak görev yapmaktadır. Yaş aralığı açısından \%33.7'si 27- 30 yaş arası kişilerden oluşmuştur. Katılımcıların \%76.9'unu üniversite mezunları oluştururken, medeni durumları açısından toplamda \%65.8'i bekârdır. Gemide yapılan görev yönünden bakıldığında, 69.9'unun güverte bölümünde çalıştığı, \%35.7'sinin ikinci veya üçüncü zabit olarak görev yaptığı görülmektedir. Toplam örneklem grubundaki kişilerden \% 36.7'si doğrudan gemi kaptanına bağlı olarak çalışıyor pozisyondadır. Ayrıca \%27.6'sının halen çalıştığ şirketteki hizmet süresi ortalama 3-5 yıldır.

Gemi görevleri, doğası gereği denizcilik sektörünün sunduğu çalışma ortamlarından en zor olanlarıdır. Bu nedenle gemi adamları belirli bir deniz hizmet süresi 
sonunda sektörün karada konuşlu birimlerinde görev almaya yönelirler. Bu durum gemide görev yapan zabitlerin büyük çoğunluğunu gençlerin oluşturması sonucunu doğurur. Zabitler açısından bakıldığında, genç bir zabitin kaptan ya da başmühendislik ünvanına ulaşması ise 30'lu yaşlarının ortalarına denk gelmektedir. $\mathrm{Bu}$ nedenle, analizde kullanılan yaş skalası, zabitlerin bir üst rütbeye çıkmaya çalıştıkları 18-35 yaş arasındaki daha sık aralıklara karşın, kaptan/başmühendis oldukları ya da karada çalışmaya yöneldikleri ortalama yaş olan 35 üstü olarak geniş ve tek bir aralıkla düzenlenmiştir.

Tablo 1. Gemi adamlarının demografik verileri

\begin{tabular}{clll}
\hline $\begin{array}{c}\text { Demografik } \\
\text { Değişken }\end{array}$ & \multicolumn{1}{c}{ Gruplar } & $\mathrm{n}$ & $\%$ \\
\hline Cinsiyet & Erkek & 158 & 79.4 \\
Medeni & Eadın & 41 & 20.6 \\
durum & Bekâr & 68 & 34.2 \\
& İlköğretim & 131 & 65.8 \\
Öğrenim & Lise & 11 & 5.5 \\
durumu & 2 yillık & 22 & 11.1 \\
& Yüksekokul & 13 & 6.5 \\
& 4 yıllık fakülte & 153 & 76.9 \\
\hline
\end{tabular}

\begin{tabular}{clll}
\hline & $18-22$ yaş & 30 & 15.1 \\
Yaş & 23-26 yaş & 37 & 18.6 \\
& 27-30 yaş & 67 & 33.7 \\
& 31-35 yaş & 25 & 12.6 \\
Çalıştı̆̆ & 35 yaş üstü & 40 & 20.1 \\
bölüm & Güverte & 139 & 69.8 \\
& Makine & 50 & 25.1 \\
& Kamara & 10 & 5.0 \\
& Kaptan & 12 & 6.0 \\
& 1. Zabit & 25 & 12.6 \\
Çalıştığ 1 & 2/3. Zabit & 71 & 35.7 \\
pozisyon & Baş Mühendis & 6 & 3.0 \\
& 2. Mühendis & 12 & 6.0 \\
& 3/4. Mühendis & 27 & 13.6 \\
& Güverte personel & 29 & 14.6 \\
& Makina personel & 8 & 4.0 \\
& Kamara personeli & 9 & 4.5 \\
Bağlı olduğu & Kaptan & 73 & 36.7 \\
amir & Baş Mühendis & 31 & 15.6 \\
& 1. Zabit & 59 & 29.6 \\
& 2. mühendis & 13 & 6.5 \\
Çalışma & 1 yıldan az & 43 & 21,6 \\
süresi & 1 y1l- 2 yıl & 40 & 20,1 \\
& 3 yıl-5 y1l & 55 & 27,6 \\
& 5 yıldan çok & 39 & 19,6 \\
\hline & & &
\end{tabular}

Tablo 2. Minesota İş tatmin ölçeği ifadelere ait betimsel istatistikler ve güvenilirlik analizi

\begin{tabular}{|c|c|c|c|c|c|}
\hline Boyutlar & Gemi adamı İș Tatmin Ölçeği ile İlgili Maddeler & $\begin{array}{c}\text { Ortal } \\
\text { ama }\end{array}$ & $\begin{array}{l}\text { Standart } \\
\text { Sapma }\end{array}$ & $\begin{array}{c}\text { Genel } \\
\text { Ortalama }\end{array}$ & $\begin{array}{l}\text { Cronbach } \\
\text { Alfa }\end{array}$ \\
\hline \multirow{9}{*}{$\begin{array}{l}\text { Bireysel } \\
\text { düzeyde iş } \\
\text { tatmini }\end{array}$} & 1.)İşim beni her zaman memnun eder. & 3.28 & 0.93 & \multirow{9}{*}{2.85} & \multirow{9}{*}{0.85} \\
\hline & 7.)İşimde, vicdanıma aykırı olmayan şeyleri yaparım. & 2.93 & 0.77 & & \\
\hline & 8.)Bana sabit bir iş olanağı sağlar. & 2.80 & 0.80 & & \\
\hline & $\begin{array}{l}\text { 9.)İşimde, başkaları için bir şeyler yapabilme imkânım } \\
\text { vardır. }\end{array}$ & 3.12 & 0.72 & & \\
\hline & 10.)Kişilere ne yapacaklarını söyleme hakkına sahibim. & 2.95 & 0.79 & & \\
\hline & $\begin{array}{l}\text { 11.)Bana kendi yeteneklerimi kullanma şansı } \\
\text { vermektedir. }\end{array}$ & 2.40 & 0.78 & & \\
\hline & 12.)İş ile ilgili kararlarım uygulamaya konmaktadır. & 2.53 & 0.83 & & \\
\hline & 13.)Yaptığım iş ve karşılığında aldığım ücret yeterlidir. & 2.95 & 0.82 & & \\
\hline & 14.)İşimde, terfi olană̆ım vardır. & 2.66 & 0.87 & & \\
\hline \multirow{5}{*}{$\begin{array}{l}\text { Örgütsel } \\
\text { düzeyde iş } \\
\text { tatmini }\end{array}$} & 2.)Bana tek başıma çalışma olanağ verir. & 2.81 & 0.89 & \multirow{5}{*}{3.02} & \multirow{5}{*}{0.78} \\
\hline & $\begin{array}{l}\text { 3.)Bana ara sıra değişik şeyler yapabilme şansı } \\
\text { vermektedir. }\end{array}$ & 3.00 & 0.93 & & \\
\hline & 4.)Bana toplumda saygın bir kişi olma şansı vermektedir. & 3.51 & 0.88 & & \\
\hline & 15.)İşimde, kararlarımı uygulama konusunda özgürüm. & 2.84 & 0.89 & & \\
\hline & $\begin{array}{l}\text { 18.)Çalışma arkadaşlarım birbirleri ile iyi } \\
\text { anlaşmaktadırlar. }\end{array}$ & 2.92 & 0.75 & & \\
\hline \multirow{8}{*}{$\begin{array}{l}\text { Yönetsel } \\
\text { düzeyde iş } \\
\text { tatmini }\end{array}$} & 5.)Yöneticilerimin idare tarzından memnunum. & 2.92 & 0.89 & \multirow{8}{*}{2.85} & \multirow{8}{*}{0.86} \\
\hline & 6.)Yöneticilerim karar verme konusunda yeteneklidir. & 2.87 & 0.85 & & \\
\hline & $\begin{array}{l}\text { 16.)İşimi yaparken kendi yöntemlerimi kullanabilme } \\
\text { şansım vardır. }\end{array}$ & 2.79 & 0.89 & & \\
\hline & 17.)Çalışma şartlarından memnunum. & 2.78 & 0.83 & & \\
\hline & 19.)Yaptığım iyi bir iş karşılığında takdirdir edilirim. & 3.07 & 0.59 & & \\
\hline & 20.)Yaptığım iş karşılığında başarı hissi duyarım. & 2.64 & 0.69 & & \\
\hline & Tatmin Puan Ortalaması & & & & \\
\hline & & 2.89 & 0.82 & & \\
\hline
\end{tabular}


Tablo 2'de Minesota İș Tatmin Ölçeği konusunda yöneltilen sorulara ilişkin alınan cevapların ortalama değerleri ile genel ortalamaları gösterilmiştir. Bu sonuçlar göstermektedir ki gemiadamlarının örgütsel tatmin düzeyleri $(3,02)$, ortalama değer olan 3'ün üstündedir. Bu durum gemiadamlarının örgütsel düzeydeki tatmin düzeylerinin diğer tatmin alanlarına göre daha yüksek olduğunun iyi bir göstergesidir. Tabloda, çalışanların genel iş tatmin düzeyi, sorulmuş olan tüm sorulara verilen cevapların ortalaması alınarak elde edilmiştir. Buradan gemiadamlarının genel iş tatmin düzeyinin 2,89 ile ortalama düzeyin altında olduğu görülmektedir.

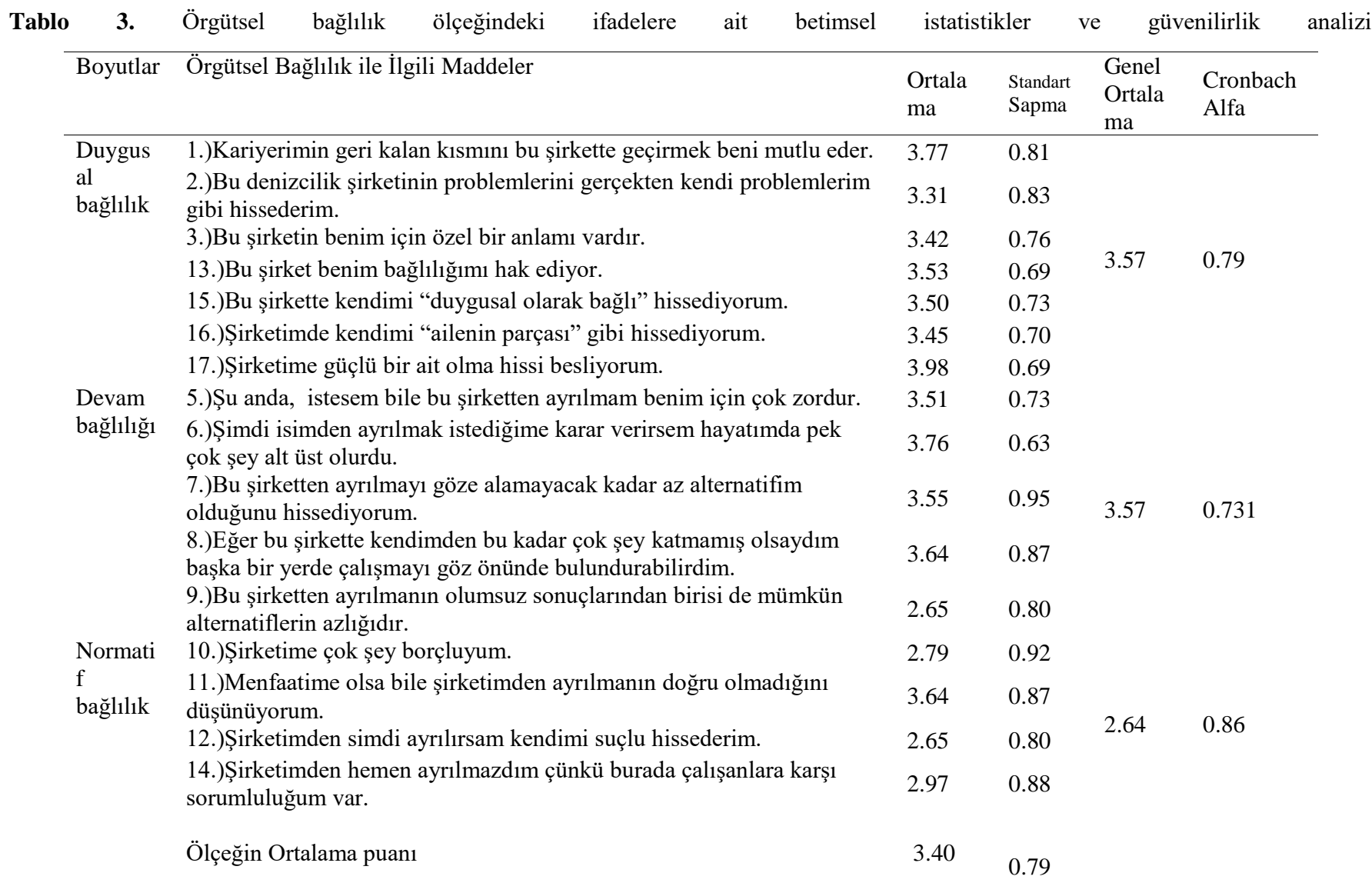

Tablo 3 Allen ve Meyer Örgütsel Bağlılık Ölçeği doğrultusunda sorulara verilen cevapları göstermektedir. Tabloda cevapların ortalamalarının yanı sıra boyutların genel ortalamaları da sunulmuştur. Buna göre katılımcıların örgütsel bağlılığı değerlendirildiğinde; devam bağlılığının ve duygusal bağlılığın 3,57 ile ortalama değerlerin üzerinde olduğu, buna karşın, normatif bağlılığın 2.64 ile görece olarak düşük olduğu görülmektedir. Genel ortalamaya bakıldığında ise gemi adamlarının örgütsel bağlılığının 3,49 ile ortalamanın üzerinde olduğu tespit edilmektedir. 
Tablo 4. İş tatmini ve örgütsel bağlılık puanlarının öğrenimlerine göre ANOVA ve Post-Hoc Tukey HSD Testi sonuçları

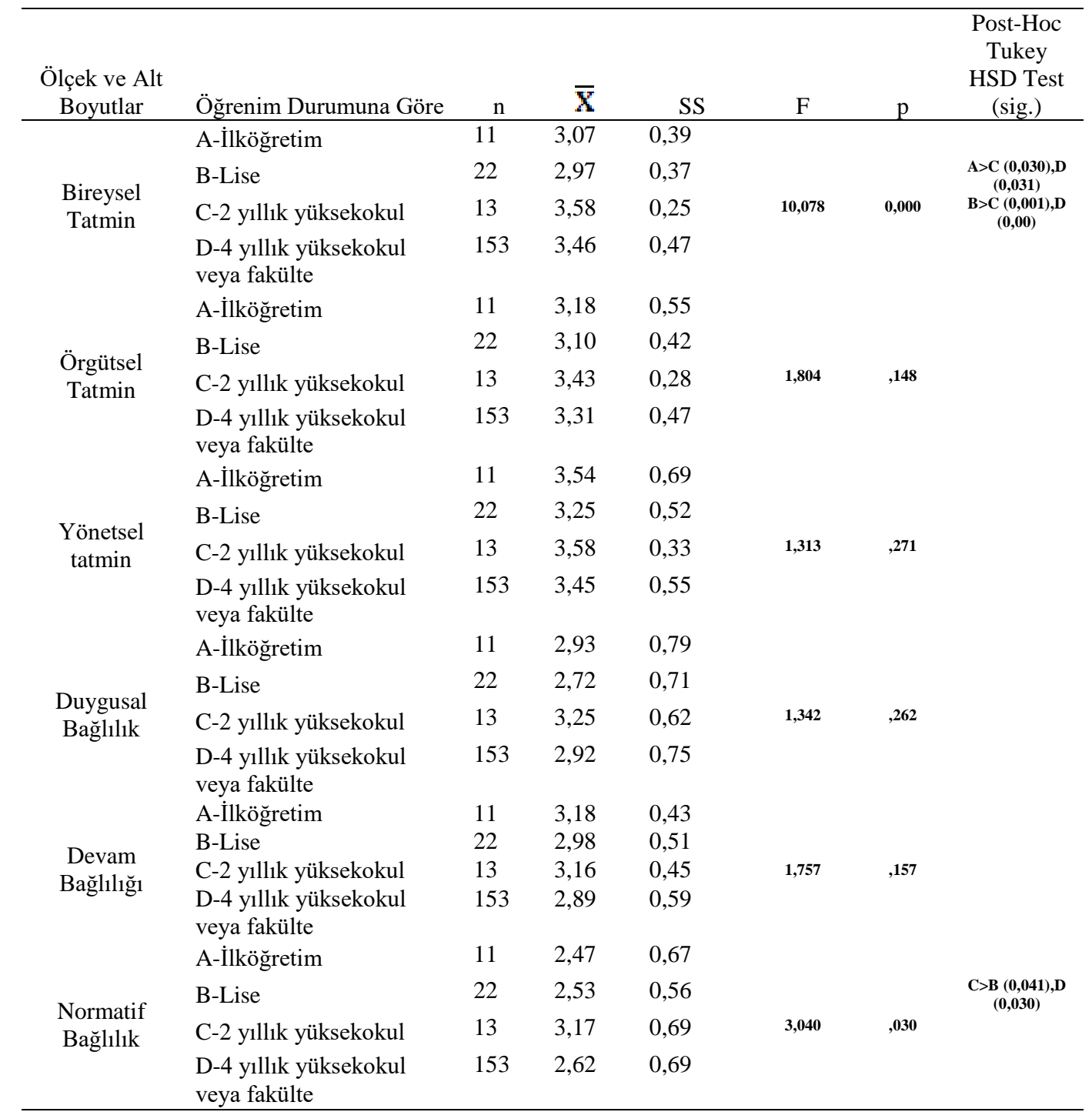

Tablo 4, iş tatmini ve örgütsel bağlılık düzeylerinin katılımcının öğrenim durumuna göre nasıl değişiklik gösterdiğini araştıran ANOVA ve Post-Hoc Tukey HSD testinin sonuçlarını göstermektedir. Tablo, bireysel tatmin seviyesinin öğrenim düzeyine bağlı olarak değiştiğini $(p=0,000)$ ortaya koymaktadır. Bu tablodan ortaya çıkan sonuca göre öğrenim düzeyleri ilköğretim ve lise olan katılımcıların bireysel tatmin düzeyi ortalaması, öğrenim düzeyi 2 yıllık meslek yüksekokulları ve 4 yıllık fakülte olan katılımcılara göre anlamlı düzeyde daha yüksektir. Buna göre öğrenim düzeyinin bireysel tatmin üzerinde ters orantılı bir etki yaptığı, öğrenim seviyesi arttıkça bireysel tatmin düzeyinin azaldığı söylenebilir.
Öte yandan normatif bağlılık düzeylerinin de katılımcıların öğrenim seviyesine bağlı olarak değiştiği $(p=0.030)$ tespit edilmektedir (Tablo 4). 2 yıllık yüksekokulu mezunu olanların normatif bağlılık düzeyi ortalamaları lise ve ilköğretim düzeyinde öğrenim görmüş olan katılımcılara göre daha yüksektir. Yine bu göstermektedir ki öğrenim durumu normatif bağlılık üzerinde etkilidir ve 2 yıllık mezunlarının Normatif bağlılık düzeyleri daha yüksektir.

Ulaşılan sonuçlar, bireysel tatmin ve normatif bağlılık değerlendirmesi kapsamında H1 ifadesinin kabul edildiğini göstermektedir. 
Tablo 5. İş tatmini ve örgütsel bağlılık puanlarının gemideki pozisyona göre ANOVA ve Post-Hoc Tukey HSD Testi sonuçları

\begin{tabular}{|c|c|c|c|c|c|c|c|}
\hline $\begin{array}{l}\text { Ölçek ve Alt } \\
\text { Boyutlar }\end{array}$ & $\begin{array}{c}\text { Gemideki pozisyona } \\
\text { göre }\end{array}$ & $\mathrm{n}$ & $\overline{\mathrm{X}}$ & SS & $\mathrm{F}$ & $\mathrm{p}$ & $\begin{array}{l}\text { Post-Hoc } \\
\text { Tukey } \\
\text { HSD Test } \\
\text { (sig.) }\end{array}$ \\
\hline \multirow{10}{*}{$\begin{array}{l}\text { Bireysel } \\
\text { Tatmin }\end{array}$} & A-Kaptan & 12 & 3,46 & .46 & \multirow{9}{*}{5,748} & \multirow{9}{*}{,000 } & \\
\hline & B-Birinci Zabit & 25 & 3,72 & 29 & & & $\mathbf{B}>\mathbf{G}(\mathbf{0}, \mathbf{0 0}), \mathbf{H}$ \\
\hline & C-2/3. Zabit & 71 & 3,40 & 35 & & & $\begin{array}{l}(0,00), \mathbf{I}(0,0124) \\
\mathbf{C}>\mathrm{H}(\mathbf{0 , 0 1 1 )}\end{array}$ \\
\hline & D-Baş Mühendis & 6 & 3,61 & 31 & & & $\mathrm{D}>\mathrm{H}(\mathbf{0 , 0 2 6 )}$ \\
\hline & E-İkinci Mühendis & 12 & 3,70 & 26 & & & 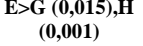 \\
\hline & F-3/4. Mühendis & 27 & 3,36 & ,56 & & & \\
\hline & G-Güverte Personeli & 29 & 3,16 & 67 & & & \\
\hline & H-Makine Personeli & 8 & 2,80 & ,33 & & & \\
\hline & I-Kamara Personeli & 9 & 3,13 & ,36 & & & \\
\hline & A-Kaptan & 12 & 3,40 & ,31 & \multirow{9}{*}{, 880} & \multirow{9}{*}{, 534} & \\
\hline \multirow{8}{*}{$\begin{array}{l}\text { Örgütsel } \\
\text { Tatmin }\end{array}$} & B-Birinci Zabit & 25 & 3,31 & ,31 & & & \\
\hline & C-2/3. Zabit & 71 & 3,30 & ,42 & & & \\
\hline & D-Baş Mühendis & 6 & 3,50 & ,32 & & & \\
\hline & E-İkinci Mühendis & 12 & 3,33 & ,37 & & & \\
\hline & F-3/4. Mühendis & 27 & 3,28 & ,45 & & & \\
\hline & G-Güverte Personeli & 29 & 3,11 & ,73 & & & \\
\hline & H-Makine Personeli & 8 & 3,17 & 49 & & & \\
\hline & I-Kamara Personeli & 9 & 3,40 & 48 & & & \\
\hline \multirow{10}{*}{$\begin{array}{l}\text { Yönetsel } \\
\text { tatmin }\end{array}$} & A-Kaptan & 12 & 3,38 & 64 & \multirow{9}{*}{1,431} & \multirow{9}{*}{, 186} & \\
\hline & B-Birinci Zabit & 25 & 3,59 & 41 & & & \\
\hline & C-2/3. Zabit & 71 & 3,45 & 45 & & & \\
\hline & D-Baş Mühendis & 6 & 3,41 & 17 & & & \\
\hline & E-İkinci Mühendis & 12 & 3,68 & 47 & & & \\
\hline & F-3/4. Mühendis & 27 & 3,41 &, 58 & & & \\
\hline & G-Güverte Personeli & 29 & 3,28 & ,79 & & & \\
\hline & H-Makine Personeli & 8 & 3,14 & ,46 & & & \\
\hline & I-Kamara Personeli & 9 & 3,70 &, 51 & & & \\
\hline & A-Kaptan & 12 & 3,03 & ,94 & \multirow{9}{*}{1,084} & \multirow{9}{*}{,376 } & \\
\hline \multirow{8}{*}{$\begin{array}{l}\text { Duygusal } \\
\text { Bağl1l1k }\end{array}$} & B-Birinci Zabit & 25 & 3,13 & 61 & & & \\
\hline & C-2/3. Zabit & 71 & 2,98 & ,75 & & & \\
\hline & D-Baş Mühendis & 6 & 3,09 & 91 & & & \\
\hline & E-İkinci Mühendis & 12 & 2,91 & ,75 & & & \\
\hline & F-3/4. Mühendis & 27 & 2,84 & ,71 & & & \\
\hline & G-Güverte Personeli & 29 & 2,75 & ,78 & & & \\
\hline & H-Makine Personeli & 8 & 2,39 & ,79 & & & \\
\hline & I-Kamara Personeli & 9 & 2,95 &, 54 & & & \\
\hline \multirow{9}{*}{$\begin{array}{l}\text { Devam } \\
\text { Bağlılığ }\end{array}$} & A-Kaptan & 12 & 2,88 & 67 & \multirow{9}{*}{1,303} & \multirow{9}{*}{,244 } & \\
\hline & B-Birinci Zabit & 25 & 2,76 & ,50 & & & \\
\hline & C-2/3. Zabit & 71 & 3,00 & 60 & & & \\
\hline & D-Baş Mühendis & 6 & 3,06 & 10 & & & \\
\hline & E-İkinci Mühendis & 12 & 2,68 & ,40 & & & \\
\hline & F-3/4. Mühendis & 27 & 2,93 &, 55 & & & \\
\hline & G-Güverte Personeli & 29 & 2,93 & 68 & & & \\
\hline & H-Makine Personeli & 8 & 2,80 & 45 & & & \\
\hline & I-Kamara Personeli & 9 & 3,31 &, 42 & & & \\
\hline \multirow{9}{*}{$\begin{array}{l}\text { Normatif } \\
\text { Bağgll1k }\end{array}$} & A-Kaptan & 12 & 2,66 & 1,02 & \multirow{9}{*}{, 253} & \multirow{9}{*}{,980 } & \\
\hline & B-Birinci Zabit & 25 & 2,67 & ,48 & & & \\
\hline & C-2/3. Zabit & 71 & 2,66 &, 75 & & & \\
\hline & D-Baş Mühendis & 6 & 2,66 & ,76 & & & \\
\hline & E-İkinci Mühendis & 12 & 2,68 & 67 & & & \\
\hline & F-3/4. Mühendis & 27 & 2,62 & 65 & & & \\
\hline & G-Güverte Personeli & 29 & 2,62 & 67 & & & \\
\hline & H-Makine Personeli & 8 & 2,31 &, 51 & & & \\
\hline & I-Kamara Personeli & 9 & 2,66 & 64 & & & \\
\hline
\end{tabular}

içerisinde ayrıca başmühendisin, ikinci mühendisin ve

Tablo 5 bireysel tatmin düzeyinin, kişinin gemideki pozisyonuna göre değiştiğini $(\mathrm{p}=0.000)$ göstermektedir. Araştırmaya katılan kişilerden, birinci zabit rütbesinde olanların bireysel tatmin düzeyleri ortalamalarının, araştırmaya katılan diğer gemiadamlarının (güverte ve makine personeli ve kamarotlar) ortalamalarından anlamlı derecede yüksek olduğu tespit edilmiştir. Örneklem grubu ikinci/üçüncü zabitin bireysel tatmin düzeylerinin diğer makine personelinden, buna karşılık ikinci mühendisin bireysel tatmin seviyesinin güverte personelinden de anlamlı düzeyde yüksek olduğu görülmektedir

Ulaşılan sonuçlar, bireysel tatmin düzeyi değerlendirmesi kapsamında H2 ifadesinin kabul edildiğini göstermektedir. 
Tablo 6. İş tatmini ve örgütsel bağll1ık puanlarının bulunduğu firmadaki çalışma süresine göre ANOVA ve Post-Hoc Tukey HSD Testi sonuçları

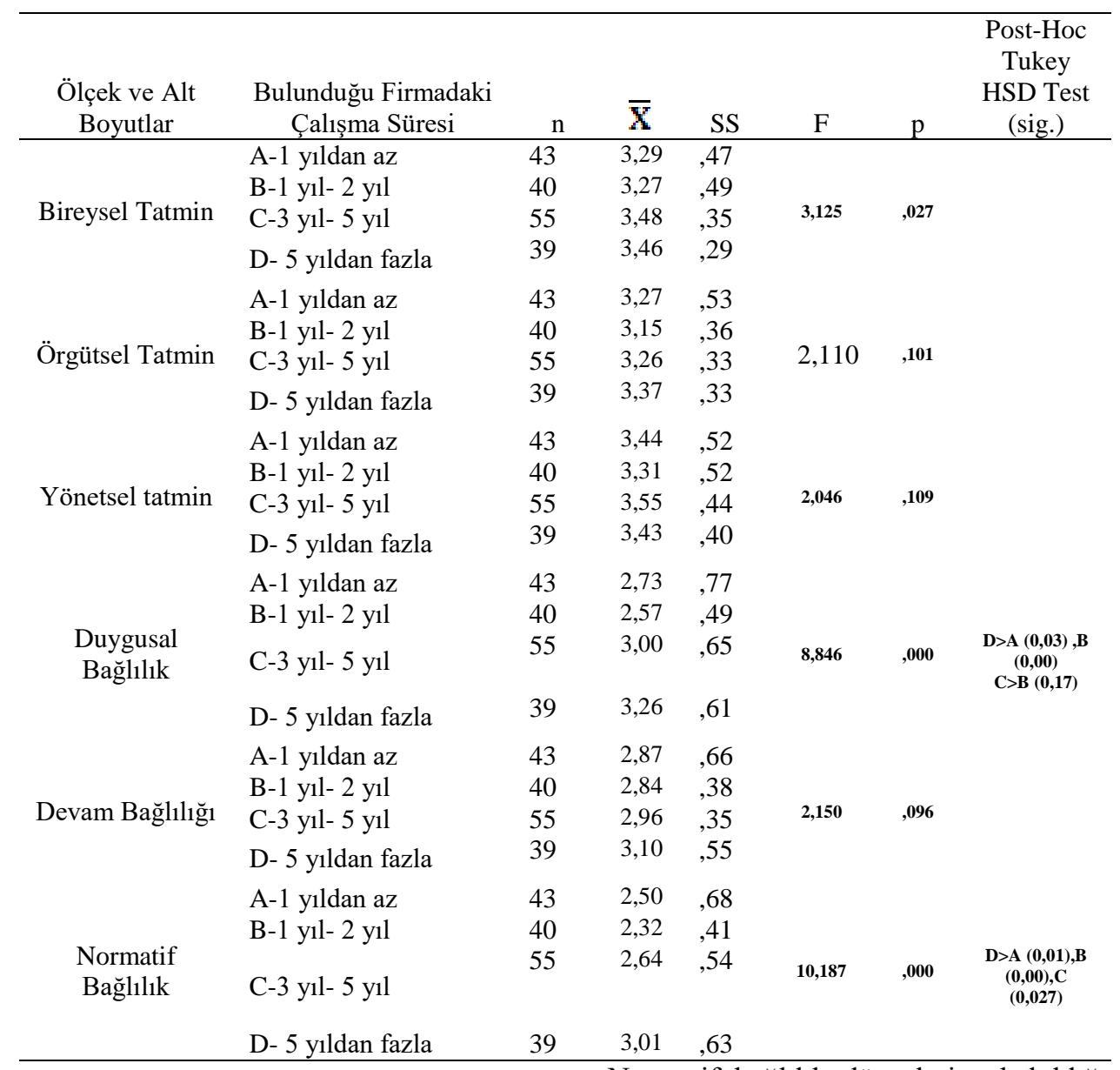

Tablo 6 duygusal bağlılık ve normatif bağlılık düzeylerinin, bir şirkette çalışılan zaman periyoduyla değiştiğini $(\mathrm{p}=0.000)$ göstermektedir. Çalışma süresi 5 yılı aşan personelin firmaya olan duygusal bağlılık seviyesinin aynı yerde bir yıldan az ya da 1-2 yıl çalışan kişilerden, çalışma süresi 3-5 yıl olan çalışanların bağlılık seviyelerinin ise, yine 1-2 yıl çalışan personelden anlamlı bir düzeyde yüksek olduğu tespit edilmiştir.
Normatif bağlılık düzeylerine bakıldığında, yine çalışma süresi 5 yılı aşan personelin, çalışma süreleri birkaç aydan 3-5 y1la kadar olan personele göre anlamlı seviyede daha yüksek bağlılığa sahip oldukları tespit edilmektedir.

Ulaşılan sonuçlar, duygusal bağl1lık ve normatif bağlılık düzeyleri için H3'nin ifadesinin kabul edildiğini göstermektedir. 
Tablo 7. İş tatmini ve örgütsel bağlılık puanlarının bağlı olduğu amire göre ANOVA ve Post-Hoc Tukey HSD Testi sonuçları

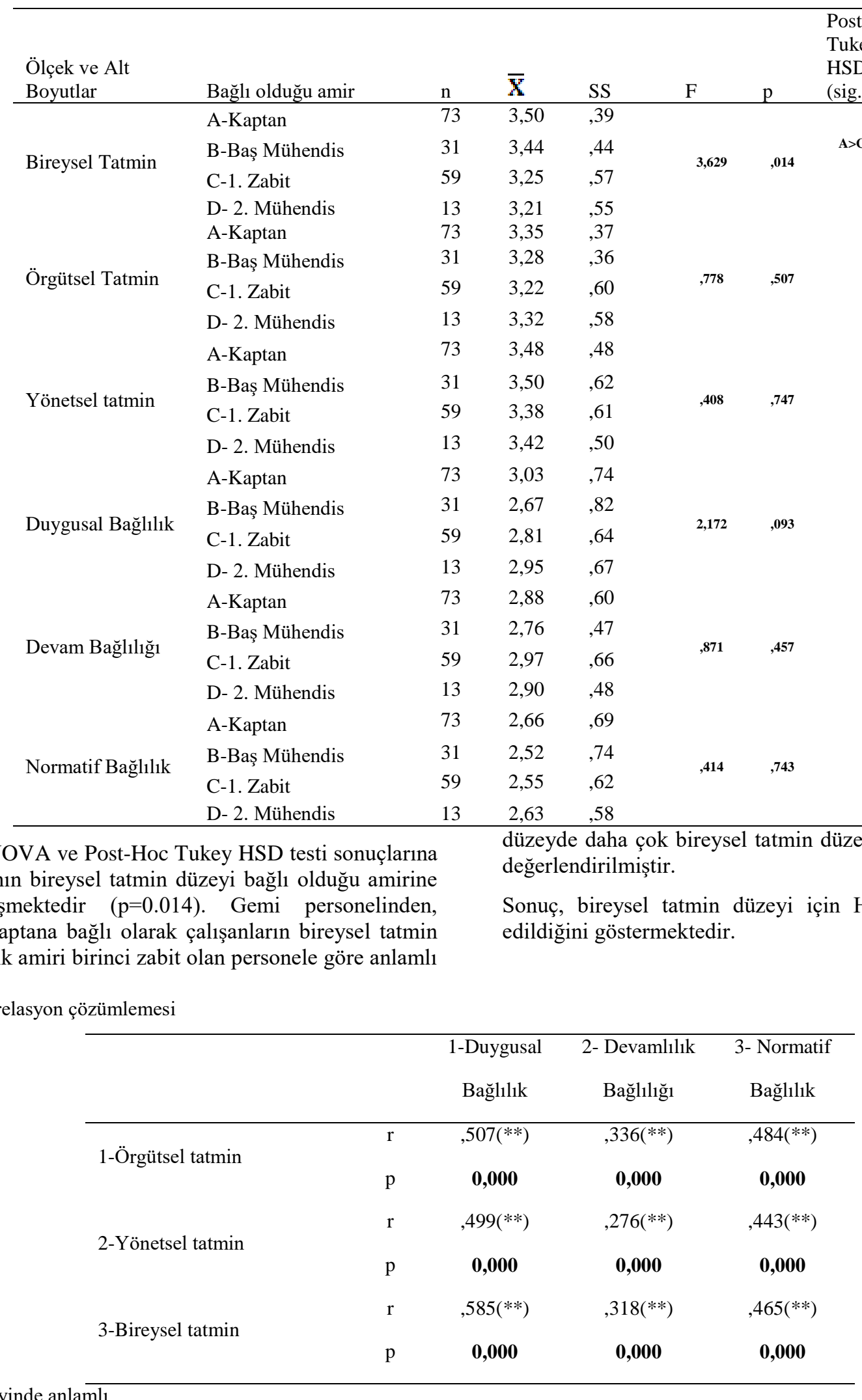

** 0.01 düzeyinde anlamlı

Tablo 8 , iş tatmini boyutlarının örgütsel bağlılık boyutları ile ilişkisinin anlaşılması için yapılmış olan korelasyon çözümlemesinin sonuçlarını göstermektedir. Tablo, örgütsel iş tatmini ile duygusal bağlılık arasında orta düzeyde pozitif ve anlamlı bir ilişki $(r=0.507, p<0,01)$ olduğunu ortaya koymaktadır. Bu ilişki, çalışanların şirketlerine yönelik iş tatmin düzeyinin artması ile örgüte karşı duygusal bağlılıklarının da arttığını göstermektedir. Bu sonuç H5 hipotezini doğrudan destekler niteliktedir.

Buna karşılık duygusal bağlılık üzerinde de aynı yönelimli fakat daha zayıf etkiler tespit edilmiştir. Burada, yönetsel iş tatmininin zayıf fakat pozitif bir düzeyde $(\mathrm{r}=0.499, \mathrm{p}<0,01)$ ile duygusal bağlılıkla ilişkili olduğu tespit edilmiştir. Öte yandan bireysel iş tatmini ile duygusal bağlılık arasında 
orta düzeyde pozitif ve anlamlı bir ilişki $(\mathrm{r}=0,585, \mathrm{p}<0,01)$ olduğu görülmektedir.

Devamlılık bağlılı̆̆ı açısından bakıldığında; örgütsel iş tatmini ile zayıf düzeyde pozitif $(\mathrm{r}=0.336, \mathrm{p}<0,01)$, yönetsel iş tatmini ile zayıf düzeyde pozitif $(\mathrm{r}=0.276, \mathrm{p}<0,01)$, ve bireysel iş tatmini ile arasında zayıf düzeyde pozitif ve anlamlı bir ilişki $(\mathrm{r}=0.318, \mathrm{p}<0,01)$ olduğu tespit edilmiştir.

Normatif bağlılık açısından da durumun pek farklı olmadığı görülmektedir. Normatif bağlılığın, örgütsel iş tatmini ile zayıf düzeyde pozitif $(r=0.484, p<0,01)$, yönetsel iş tatmini ile zayıf düzeyde $(r=0.443, p<0,01)$ ve bireysel iş tatmini ile zayıf düzeyde $(\mathrm{r}=0,465, \mathrm{p}<0,01)$ pozitif ve anlamlı bir ilişki olduğu tespit edilmiştir. Korelasyon analizi sonuçları H6, H7, H8, H9 ve H10 hipotezlerini desteklemektedir.

\section{Değerlendirme ve Sonuç}

$\mathrm{Bu}$ çalışma günümüz denizcilik literatürüne örgütsel bağlılık ve iş tatmini arasındaki ilişkileri çözümlemek açısından katkıda bulunmaya çalışmıştır. Yapılan araştırma, gemiadamlarının iş tatminleri ile şirketlerine hissettikleri örgütsel bağlılık düzeyleri arasındaki ilişkiyi ortaya koymayı hedeflemiştir. Bununla beraber, demografik unsurların; bireylerin iş tatmini ve örgütsel bağlılıklarına olan etkilerini tespit etmek amacını gütmüş, veri toplama aracı olarak anket yöntemini kullanmıştır.

Yapılan çözümlemeler, gemi adamlarının iş tatminlerinin orta seviyenin bir miktar altında olduğunu göstermiştir. Örgütsel bağlılık seviyelerinin ise orta seviyenin biraz üzerinde olduğu ve bu seviyenin de çalışanların demografik özelliklerine bağlı olarak değiştiği tespit edilmiştir. Etkin olan demografik faktörler; öğrenim durumu, gemi organizasyonu içindeki pozisyon, şirkette çalışma süresi bağlı bulunulan amirim kim olduğudur.

Tespit edilen sonuçlar ayrıca gemiadamlarının eğitim düzeyi arttıkça bireysel tatminlerinin azaldığını işaret etmektedir. Bunun nedeninin, eğitim düzeyi yüksek olan gemiadamlarının sahip oldukları yetenekleri ve donanımlarıyla kendilerine sunulan koşullardan daha iyi ortamlarda çalışabileceklerini ve düşük eğitim seviyesine sahip gemiadamlarına göre daha kolay iş bulabileceklerini düşünmelerinin olduğu tespit etmek yerinde olacaktır. Tersi bir yaklaşım da, ilköğretim ve lise mezunu gemiadamlarının iş tatmin düzeylerinin neden yüksek olduğunu açıklayacaktır.

Hiyerarşik yapı içerisinde sahip olunan pozisyon açısından yapılan incelemede varılan sonuçlar göstermektedir ki birinci zabit rütbesine sahip olan katılımcıların bireysel tatmin düzeyi daha alt kademelerde çalışan gemiadamlarına göre anlamlı şekilde yüksektir. Bunun birden fazla doğal nedeni olduğundan söz edilebilir. Öncelikle bu rütbe gemi içerisindeki yeri açısından yönetici sınıfına aittir. $\mathrm{Bu}$ durum birinci zabitlere altında çalışanların amiri olma böylelikle de yüklenen sorumluluğa koşut olacak şekilde emir verme yetkisi verir. $\mathrm{Bu}$ yetki şirket işleyişine bağlı olarak astlarının performans değerlendirilmelerinde de birinci zabite söz hakkı verebilir. Bu yetkilerin gereğince üstlenilmesinin ve kullanılmasının yanı sıra birinci zabitlerin maaş seviyesinin daha alt seviyede çalışan zabitler dâhil tüm personelden de sıçrama yapacak şekilde yüksek olması da bireysel tatmin düzeylerini artırmaktadır. $\mathrm{Bu}$ tespit denizcilik sektörü için bir kılavuz olarak kullanılabilir. Bu açıdan bakarak şirketler; birinci zabitlerin gemi personelini daha etkin bir şekilde motive edebilecek ve kendini bir rol model olarak sunabilecek şekilde yönlendirmeye, yetiştirmeye ve ilave eğitimlerle donanımlarını artırmaya çalışmalıdır.

Çalışmadan elde edilen bir başka sonuç da normatif ve duygusal bağlılık düzeylerinin zaman ölçeğinde artıyor olmasıdır. Çözümleme sonuçları göstermektedir ki, bir şirkette çalışma süresi arttıkça çalışanların duygusal ve normatif bağlılık düzeyleri de yükselmektedir. Bu sonuç denizcilik sektörü için başka bir ipucu barındırmaktadır. Firmalar personelinin kendileriyle uzun süreler çalışmalarını sağlayacak özendirici tedbirler alırlarsa, uzun dönemde bu çaba onlara kurumsal bağlılı̆̆ 1 yüksek yaptığı işi seven ve profesyonel beklentilerine paralel olarak kurumu için kendisini sorumlu hisseden personele sahip olma şansı verecektir.

Gemi organizasyonu içinde kişinin bulunduğu pozisyon açısından bakıldığında ortaya çıkan önemli diğer bir sonuç da; amiri gemi kaptanı olan personelin, amiri birinci zabit olanlara göre bireysel tatminlerinin çok daha yüksek olduğudur. Bu durum birden fazla gerekçe ile açıklanabilir. Birincisi, kaptana doğrudan bağlı olan zabitlerin eğitim ve mesleki kültür düzeyleri kendininkilere yakın olan gemi kaptanı ile kurduğu ilişkilerde bu durum da yansımakta, hiyerarşiden uzaklaşmadan daha esnek ve sicak ilişki kurabilmek mümkün olabilmektedir. Bunun yanı sıra genç zabitlerin; yetkinliğini, genel kültürünü ve mesleki bilgisini örnek alabilecekleri bir gemi kaptanına olan saygı ve sevgileri artarken aynı zamanda onu rol model alabilmektedir. Diğer tarafta, güverte ve kamara personeli iş bakımından doğrudan birinci zabite bağlılardır ve idari açıdan amir olarak karşılarında organizasyonu temsilen birinci zabite yer alır. Kaptan ve zabitler arasındaki esnek ilişki tarzı; eğitim, kültür farkı, görev ilişkisi ve sosyal nedenlerle birinci zabit ve bağlı bulunan personeli arasında mümkün olmamaktadır.

$\mathrm{Bu}$ çalışmadan çıkarılan sonuçlar, denizcilik sektöründe istihdam edilen gemiadamlarının bireysel iş tatminlerinin, böylelikle de şirkete olan bağlılıklarının ve katkılarının artırılmasında yardımcı olabilecek ipuçları vermiştir. Görülmektedir ki ücret artışı, bireye kendi yeteneklerini kullanabilme ve kararlara katılabilme imkânlarıyla beraber uygulandığında daha verimli sonuçlar doğurmakta, iş tatmini yüksek ve çalışma isteği artmış bir çalışanlar grubu ortaya çıkarmaktadır. Denizcilik şirketleri bu yönde düzenlemelere giderek yetişmiş ve yetkin personelini elde tutmaya çalışmalıdır. Böyle yaparak nihayetinde daha çalışkan, azimli ve bağlılık duygusuyla yüklenmiş olan gemiadamlarının firma içindeki sayıları aratacak, bu kişiler kendilerine verilen görevleri daha titiz, dikkatli ve şirketlerini koruyacak şekilde ifa edeceklerdir. Sonuçta şirketler de bu durumdan kazançlı çıkacaklardır. Personel üzerindeki bu olumlu etki, daha geniş açıdan bakıldığında seyir emniyeti başta olmak üzere gemilerin denizdeki operasyonlarının emniyetle yapılmasını destekleyecektir. Diğer yönden bakıldığında, yaptığı iş şirketi tarafindan takdir edilen, değer verilen gemi çalışanları liman devleti kontrolleri başta olmak üzere, kargo dâhil tüm idari ve operasyonel liman operasyonlarında da şirketinin çıkarlarını gereği gibi gözetecek ve gemisini ve şirketini zarara uğratabilecek hiçbir olasılığa izin vermeyecek şekilde kendinden ilave katkılarda bulunabilecektir. 
Bireyin terfi yolunun açık olduğunu görmesi ve örgütsel düzeyde oturmuş bir sistem ve iyi tanımlanmış kurallar kişinin iş tatminini doğrudan etkileyen faktörlerdir. Çalışma ortamında sağlanan iş huzuru ve güven duygusu da bireyin iş tatminini artıran unsurlardır. Yönetsel olarak hissedilen iş tatmini ise çalışma ortamında sağlanan adalet duygusudur. Birey çalışma ortamının adil olduğuna, yaptıkları işin takdir edildiğine inanması ve örgütü için değerli olduğunu hissetmesi onun iş tatmini düzeyini artıracak ve motivasyonunu yükseltecektir.

Araştırmaya veri sağlayan katılımcıların örgütsel bağlılık boyutlarından; normatif bağlılık düzeylerinin, duygusal ve devamlılık bağlılık düzeylerine oranla daha düşük olduğu görülmüştür. Denizcilik şirketleri bu verilerden faydalanarak, kendi çalışanlarının normatif bağlılık düzeylerini yükseltecek şekilde düzenlemelere gitmeli, personelinin bireysel, örgütsel ve yönetsel iş tatminlerini yükseltmelidir.

Günümüzde küresel boyutta varlığını sürdüren denizcilik mesleğindeki yetişmiş ve kaliteli işgücü ihtiyacı yakın gelecekte de devam edecek gibi görünmektedir. $\mathrm{Bu}$ nedenle, dünya ölçeğinde gemi adamına duyulan ihtiyaç ve mesleğe özel personel değişim oranı dikkate alındığında, yetişmiş gemi adamlarını motive ederek elde tutmanın ne denli önemli olduğu daha iyi anlaşılabilecektir.

\section{Kaynakça}

Allen, N. J., Meyer, J. P., \& John P. (1990). The Measurement and Antecedents of Affective, Continuance and Normative Commitment to the Organization. Journal of Occupational Psychology, 63, 1-18.

Baycan, A. (1985). An Analysis Of The Several Aspects Of Job Satisfaction Between Different Occupational Groups, Yayımlanmamış Doktora Tezi. İstanbul: Boğaziçi Üniversitesi.

Bülbül, S. (2016). Örgütsel bağlılık ve İş tatmini: Bir Kamu Kurumunda Uygulaması, Yayımlanmış Yüksek Lisans Tezi. İstanbul: Nişantaşı Üniversitesi.

Erdil, O., \& Keskin, H. (2003). Güçlendirmeyle İş Tatmini, İş Stresi ve Örgütsel Bağlılık Arasındaki İlişkiler: Bir Alan Çalışması, İstanbul Üniversitesi Iş̧letme Fakültesi Dergisi, 32 (1),7-24.

Fan, L., Fei, J.,, Schriever, U., \& Fan, S. (2017). The communicative competence of Chinese seafarers and their employability in the international maritime labour market. Marine Policy, 83:137-145.
International Maritime Organization, (2008). Go to sea! A Campaign to attract entrants to the shipping industry. Campaign document, In: Organization, I.M. (Ed.).

International Maritime Organization, (2017). Day of the seafarer 2017, Campaign document. In: Organization, I.M. (Ed.). http://www.imo.org/en/About/Events/dayoftheseafar er/Pages/Day-of-the-Seafarer-20.

Meyer, J. P., \& Allen, N. J. A. (1991). Three-Component Conceptualization of Organizational Commitment, Human Resource Management Review, 1 (1), 61-89.

Nguyen, T.T., Ghaderı, H., Caesar, L.D., \& Cahoon, S., (2014). Current Challenges in the Recruitment and Retention of Seafarers: An Industry Perspective from Vietnam. The Asian Journal of Shipping and Logistics, 30(2), 217-242.

Nunnally, J. C. (1978). Assessment of Reliability. In: Psychometric Theory (2nd ed.). New York: McGraw-Hill.

Özutku, H. (2008). Örgüte duygusal, devamlılık ve normatif bağlılık ile iş performansı arasındaki ilişkinin incelenmesi, Istanbul Üniversitesi Işletme Fakültesi Dergisi, 37(2), 79-97.

Ruggunan, S., \& Kanengoni, H., (2017). Pursuing a career at sea: an empirical profile of South African cadets and implications for career awareness. Maritime Policy Management, 44 (3), 289-303.

Thai, V.V., Balasubramanyam, L., Yeoh, K.K.L., \& Norsofiana, S. (2013). Revisiting the seafarer shortage problem: the case of Singapore. Maritime Policy. Management, 40 (1), 80-94.

WEB 1:

<http://www.imo.org/MediaCentre/HotTopics/GoTo Sea/Pages/Default.aspx $>$ (Erişim Tarihi:

22.10.2019).

Weiss, D.J., Dawis, R.V., England, G.W., \& Lofquist, L.H. (1967). Manual for the Minnesota Satisfaction Questionnaire (Minneapolis MN: The University of Minnesota Press).

Yuen, K.F., Loh, H.S., Zhou, Q., \& Wong, Y.D. (2018). Determinants of job satisfaction and performance of seafarers. Transportation Research Part A, 110, 112. 